\title{
Analysis of long-term trends of world prices for agricultural products
}

\author{
Lyudmila Medvedeva ${ }^{1 *}$ and Elena Ivanova ${ }^{1}$ \\ ${ }^{1}$ Don State Technical University, Gagarin sq.1, 344003, Russia
}

\begin{abstract}
The issues related to the long-term pricing process in the world market of agricultural products are discussed in the paper. It is noted that international trade of agro-industrial products, namely the fishery commodities, is one of the key components of the global economy. A detailed analysis of export prices for agricultural products was carried out along with the current trend identification. It is noted that a qualitative analysis of long-term trends of changes of world prices for agricultural products, namely fishery products, can serve as a basis for strategic forecasting of development of the most important sectors of the Russian economy.
\end{abstract}

\section{Introduction}

It is undoubtedly that the complexity of the current economic, social, and political situation throughout the international community have a significant impact on the pricing policy in all sectors of the economy and agrobusiness is no exception. It is this industry that requires the utmost support from the state, which should also be reflected in pricing policy development, allocation of subsidies to the producers, allocation of investment loans, compensation of direct expenses, etc. [1].

Thus, the pricing of agricultural products is undergoing substantial changes and, although it is quite difficult to talk about the policy of long-term world prices now, there are analysis tools that help to identify certain trends and use them in the process of strategic forecast development, considering the identification and possible evaluation of risk events [2].

The main purpose of this study is to analyze long-term trends of world prices for products of the agricultural sector, namely fish products, and to use the results of this analysis in the process of strategic forecasting of the industry development.

It should be noted that domestic and foreign authors are actively involved in the study of issues of agricultural products pricing. They discuss the problems of pricing policy in the agricultural sector, the procedure and trends of pricing in the world agricultural market in their studies. However, there are areas that require further consideration and development, which is emphasized in this scientific article.

\section{Materials and methods}

*Corresponding author: milla1988@mail.ru 
We believe that the qualitative analysis for identification of change pattern of world prices for agricultural products can be a first step toward developing a long-term pricing strategy in this economic sector. It is true that this stage is not the only one in the development of long-term trends of world pricing, but, in our view, it is one of the main ones.

To analyze long-term trends of world prices for products of the agricultural sector the public access statistical data is used, for example, the data from the website of Russian Federal State Statistics Service, as well as the data from periodical press for the periods analyzed.

The study of the world pricing policy can be carried out using the tools of horizontal and vertical analysis, the index method, calculation of average indicators and other methods of analysis.

\section{Results}

The policy of pricing for fish products as one of the leading in the area of pricing policy development in this industry is selected as the research object in this scientific article [3-5].

We consider it necessary to begin the study of world prices for products of the agricultural sector with an analysis of change of average indicators of export prices for the fishery products, which is shown in Table 1.

Table 1. Average indicators of change of export prices for fresh and frozen fish for the period 2015-2019.

\begin{tabular}{|c|c|c|c|c|}
\hline Indicators & $\begin{array}{c}\text { Average } \\
\text { export price, } \\
\text { US dollars per } \\
\text { ton }\end{array}$ & $\begin{array}{c}\text { Annual average } \\
\text { absolute growth } \\
\text { (loss), US dollars }\end{array}$ & $\begin{array}{c}\text { Annual } \\
\text { average } \\
\text { growth rate, } \\
\%\end{array}$ & $\begin{array}{c}\text { Annual } \\
\text { average } \\
\text { growth } \\
\text { (loss) } \\
\text { rate, \% }\end{array}$ \\
\hline $\begin{array}{c}\text { Average export price for fresh } \\
\text { and frozen fish }\end{array}$ & 1676 & -10.5 & 99.3 & -0.7 \\
\hline $\begin{array}{c}\text { - trade turnover with the CIS } \\
\text { countries }\end{array}$ & 1691 & -9.5 & 99.4 & -0.6 \\
\hline $\begin{array}{c}\text { - trade turnover with far abroad } \\
\text { countries }\end{array}$ & 1255 & -25.5 & 98.1 & -1.9 \\
\hline
\end{tabular}

The results of the analysis allow us to make a conclusion that export prices for fresh and frozen fish during the researched period decreased in trade turnover both with the CIS countries and with non-CIS countries. The average export price for fresh and frozen fish amounted to USD 1676, the annual average loss was USD $10.5(0.7 \%)$. In the trade turnover with the CIS countries, the average export price for fresh and frozen fish is USD 1691 and the annual decrease amounts to USD $9.5(0.6 \%)$. In the trade turnover with nonCIS countries, the average export price for fresh and frozen fish is USD 1255 and the annual decrease amounts to USD 25.5 (1.9\%). The calculations of the export price indices for fish products are presented in Table 2.

The base indices show that the average export prices for fresh and frozen fish increased from 2016 to 2018 but decreased by $2.6 \%$ in 2019 compared to 2015 . The decrease in average prices is observed from 2017 to 2019 in relation to the previous year. The analysis of the indicators of trade turnover with non-CIS countries shows a similar situation. In trade turnover with the CIS countries prices decreased in 2016-2017 in relation to the previous year, but increased by $11.2 \%$ in 2018 compared to 2017 and by $9.1 \%$ in 2019 . 
Table 2. Export price indices for fresh and frozen fish.

\begin{tabular}{|c|c|c|c|c|c|c|}
\hline Indicators & Indices & $\mathbf{2 0 1 5}$ & $\mathbf{2 0 1 6}$ & $\mathbf{2 0 1 7}$ & $\mathbf{2 0 1 8}$ & $\mathbf{2 0 1 9}$ \\
\hline $\begin{array}{c}\text { Average export price } \\
\text { for fresh and frozen } \\
\text { fish }\end{array}$ & Base indices & - & 113.1 & 103.3 & 100.6 & 97.4 \\
\cline { 2 - 7 } & Chain indices & - & 113.1 & 91.3 & 97.4 & 96.9 \\
\hline $\begin{array}{c}\text { - trade turnover with } \\
\text { far abroad countries }\end{array}$ & Base indices & - & 113.8 & 104.2 & 101.2 & 97.7 \\
\cline { 2 - 7 } & Chain indices & - & 113.8 & 91.6 & 97.2 & 96.5 \\
\hline $\begin{array}{c}\text { trade turnover with } \\
\text { the CIS countries }\end{array}$ & Base indices & - & 99.0 & 76.4 & 84.9 & 92.6 \\
\cline { 2 - 7 } & Chain indices & - & 99.0 & 77.2 & 111.2 & 109.1 \\
\hline
\end{tabular}

Import of seafood, particularly of crab, is of great importance for the Russian Federation. It is worth mentioning that Russia is deeply involved in exporting it to South Korea.

The price situation is particularly impressive, because the general level of import prices remains rather high since June 2019, and in October it increased even more and considerably exceeded the level of the previous year.

In September, the volume of South Korean import of Russian frozen crab increased by almost $70 \%$ but was limited to less than 0.25 thousand tons and was only $6 \%$ more than in 2019. In October, it increased by more than $85 \%$ and reached more than 0.45 thousand tons, which is $277 \%$ more than in October 2019.

As a result, the total volume of Russian shipments of crab, which, according to many market experts, was represented only by the snow crab, by early November reached 2.3 thousand tons and more. This is at least $20 \%$ higher than the volume of January-October 2019 , and it lacked only about 45 tons to reach the annual volume of 2019.

The prices, which in the first half of summer began to fix at the level of USD 17.00 per $\mathrm{kg}$ (CIF), and in August reached USD 18.00 per kg and more (USD 8.20 per lb), in October practically reached USD 19.00 per $\mathrm{kg}$ (more than USD 8.60 per lb). This is, in fact, the highest price level for Russian supplies not only in the current year, but also in the previous two years, so the October results indeed look great from the perspective of interests of Russian producers. Furthermore, the prices of Russian crab are nearly 4 times higher than the prices of Chinese crab and $80 \%$ higher than the prices of crab from Namibia (Table 3 ).

Table 3. South Korea frozen crab import.

\begin{tabular}{|c|c|c|c|c|c|c|c|c|}
\hline \multirow[b]{2}{*}{ Period } & \multicolumn{2}{|c|}{$\begin{array}{l}\text { Russia } \\
\text { (king crab) }\end{array}$} & \multicolumn{2}{|l|}{$\begin{array}{l}\text { Russia } \\
\text { (other) }\end{array}$} & \multicolumn{2}{|c|}{$\begin{array}{l}\text { Namibia } \\
\text { (other) }\end{array}$} & \multicolumn{2}{|l|}{$\begin{array}{l}\text { China } \\
\text { (other) }\end{array}$} \\
\hline & tons & $\begin{array}{l}\text { USD } \\
\text { per kg }\end{array}$ & tons & $\begin{array}{l}\text { USD } \\
\text { per kg }\end{array}$ & tons & $\begin{array}{l}\text { USD } \\
\text { per kg }\end{array}$ & tons & $\begin{array}{l}\text { USD } \\
\text { per } \\
\mathrm{kg}\end{array}$ \\
\hline \multicolumn{9}{|l|}{2018} \\
\hline Total & 87 & 26.05 & 2356 & 14.76 & 573 & 8.18 & 2415 & 3.72 \\
\hline \multicolumn{9}{|l|}{2019} \\
\hline May (05) & 14 & 31.00 & 267 & 9.50 & 55 & 8.75 & 234 & 4.26 \\
\hline June (06) & - & - & 107 & 17.03 & 110 & 8.89 & 108 & 1.90 \\
\hline July (07) & 30 & 25.85 & 425 & 16.74 & - & - & 113 & 3.16 \\
\hline August (08) & 34 & 26.30 & 146 & 18.11 & - & - & 101 & 4.23 \\
\hline $\begin{array}{l}\text { September } \\
(09)\end{array}$ & 7 & 20.00 & 245 & 17.12 & 60 & 8.98 & 48 & 1.12 \\
\hline October (10) & - & - & 456 & 18.99 & 20 & 8.49 & 148 & 3.76 \\
\hline Total & 183 & 28.59 & 2313 & 15.27 & 579 & 8.73 & 1482 & 4.19 \\
\hline
\end{tabular}

The total result of Russian snow crab imports in January-October can hardly be characterized as high in terms of price, since prices increased by only $0.5 \%$ compared to the previous year and were limited to less than USD 15.30 per kg (mostly due to extremely low indicators in April and May, when more than 0.4 thousand tons of crab were supplied at price level of only USD 9.00-9.50 per kg). However, the overall picture of imports from 
Russia was quite favorable, because due to the significant volume increase the value of imports rose by almost $21 \%$ and reached USD 35 million, that is at least ten times more than the total value of frozen crab imports of other countries which are well-known suppliers of frozen snow crab in the world crab market (Canada, USA, Greenland and Norway).

The import prices of Russian products in January-October were approximately 20-25\% lower than the prices of imports from Canada and Norway, but the import volumes were ten times higher (the import of Norwegian products amounted to less than 85 tons, and the import of Canadian products did not even reach 50 tons), and therefore the dominance of Russian products in the frozen snow crab market of South Korea is persistent. It is also worth to mention the positions of Russian products in the South Korean market of frozen king crab which became the strongest this year.

Russian supplies of live king crab to South Korean ports rapidly increased in September 2019 and continued its growth in October.

This, coupled with the high activity of live opilio supplies, ensured that the import of live crab from Russia to South Korea reached a very high level, which lost a bit only to the January one. Compared to the previous year, the total volume of Russian supplies of live crab to South Korean ports was also significantly greater in October, although the volume of king crab supplies was less than in 2018. Nevertheless, the imports of Russian other live crab increased slightly in January-October compared to the previous year even in conditions of a much higher price level.

The shipments of these Russian products, which went down in July and August, increased almost threefold in September, reaching about 0.65 thousand tons, and in October increased by another $16 \%$ and almost reached 0.75 thousand tons. This was the highest figure since the beginning of the year, but the volume of October supplies was $4 \%$ less than in 2018 .

However, in September and October, when Russian producers began to actively supply products of the new fishing season in Western Kamchatka, about 1.39 thousand tons were shipped, that is $1 \%$ more than in 2018. For the first ten months of the year the imports of crab from Russia increased by almost $2 \%$ and reached about 3.5 thousand tons. The prices and volumes of crab export from Russia to South Korea are shown in Table 4.

Table 4. Crab export from Russia to South Korea.

\begin{tabular}{|l|l|l|l|l|l|l|}
\hline \multirow{2}{*}{ Period } & $\begin{array}{l}\text { Other crab, live, fresh, } \\
\text { chilled }\end{array}$ & \multicolumn{2}{l|}{ King crab, frozen } & \multicolumn{2}{l|}{$\begin{array}{l}\text { Other crab, } \\
\text { frozen }\end{array}$} \\
\cline { 2 - 7 } & tons & USD per kg & tons & USD per kg & tons & $\begin{array}{l}\text { USD per } \\
\text { kg }\end{array}$ \\
\hline 2018 & \multicolumn{7}{|l|}{} \\
\hline Total & 4814 & 27.94 & 87 & 26.05 & 2356 & 14.76 \\
\hline 2019 & \multicolumn{7}{|l|}{} \\
\hline May & 269 & 50.75 & 14 & 31.00 & 267 & 9.50 \\
\hline June & 223 & 34.78 & 0 & - & 107 & 17.03 \\
\hline July & 95 & 25.01 & 30 & 25.85 & 425 & 16.74 \\
\hline August & 154 & 30.47 & 34 & 26.30 & 146 & 18.11 \\
\hline September & 642 & 26.31 & 7 & 20.00 & 245 & 17.12 \\
\hline October & 746 & 25.20 & 0 & - & 456 & 18.99 \\
\hline Total & 3490 & 32.96 & 183 & 28.59 & 2313 & 15.27 \\
\hline
\end{tabular}

Thus, the value of imports increased by more than a quarter and reached USD 115.0 million, even in the conditions of very slight increase of the volume of supplies. This corresponds to more than $85 \%$ of the total value of imports of Russian other live crab in 2018, so that if such active supplies also take place in November-December (in the normal 
conditions in the Sea of Okhotsk this can be a highly likely course of events), the total value of imports of Russian products according to this product code will increase quite significantly (more than 1.29 thousand tons was imported in November and December 2018).

The value of imports of Norwegian products according to the same product code (in fact, it was the import of only king crab from the fishery in the Barents Sea) exceeded the annual value for 2018 by almost $27 \%$ by reaching USD 32.3 million by early November. It increased by $38 \%$ compared to January-October of the previous year, as the average import price (CIF) rose by more than $10 \%$ by reaching more than USD 41.25 per $\mathrm{kg}$, and the volume of imports increased by more than $25 \%$ and reached 0.78 thousand tons.

It is clear that the annual volume of Norwegian supplies of live king crab to the South Korean market, which fell by $14 \%$ last year amounting to nearly 0.7 thousand tons, this year will at least recover to the level of 2017, and at most will reach the level of 0.8 thousand tons or more. The price level is still unclear, since the prices began to decline in August, and in October they amounted to only USD 33.00 per $\mathrm{kg}$, which is almost USD 10.00 per kg below the July maximum.

But even in October prices were slightly higher than the previous year (by $2.3 \%$ ), and even if October price trend continues, the price total of the year will most likely be close to the level of USD 41.00 per $\mathrm{kg}$, which is nearly $10 \%$ higher than the level of 2018 and at least $20 \%$ higher than the level of 2017. Thus, the general condition of the South Korean live crab market this year totally corresponded to the interests of both Russian and Norwegian producers which took advantage of that and increased their supply shipments.

The shipments of Russian live snow crab to South Korean ports fully recovered in October 2019 after the drop in September.

It happened even though the competition increased due to the additional Russian supplies of live king crab, the new fishing season of which had already developed in full force. It is possible that the general price level was influenced by this competition because the prices decreased noticeably in comparison not only with September, but also with August.

However, the prices of imported Russian products were significantly higher compared to the previous year, but despite this the acceptance capacity was much higher than in October 2018, which further increased the breakaway of the volume of Russian snow crab imports accumulated based on the results of the first three quarters of the year.

In the summer months, the volumes of Russian shipments of live snow crab to the ports of South Korea were less than in May and, especially, in April, but reached the average level of 0.6 thousand tons or more per month. The collapse was recorded in September, since only 0.35 thousand tons were shipped during this month, which is at least $40 \%$ less than the average volume of supplies in June, July, and August.

This immediately gave rise to the opinion that the activity of shipments of opilio and other species of snow crab began to decrease because of the shift to king crab harvesting on the coast of the Sea of Okhotsk in Kamchatka, but it turned out that such pessimistic conclusions were made prematurely.

The volume of October supplies not only increased by $83 \%$ compared to September and exceeded the volume of summer shipments by $4-8 \%$, but also reached almost 0.65 thousand tons, which is $55 \%$ more than the volume of October supplies of the previous year, while a drop of more than $30 \%$ was recorded in September.

Due to such an increase, the total volume of supplies in January-October broke away from the same period of the previous year by $10.7 \%$, that is, the physical growth of imports of live snow crab from Russia reached about 6.23 thousand tons by early November and was already by 0.6 thousand tons more than in 2018 , when at the end of the year Russian supplies increased by almost $37 \%$ and reached about 6.85 thousand tons. At first glance, it 
seems obvious that the previous year's record should be beaten until early December, provided that the rates of shipments would simply remain at the level of October (Table 5).

Table 5. Export of live, fresh, chilled crab to South Korea in 2018-2019.

\begin{tabular}{|l|l|l|l|l|l|l|}
\hline \multirow{2}{*}{ Period } & \multicolumn{2}{|l|}{$\begin{array}{l}\text { Russia } \\
\text { (other crab) }\end{array}$} & \multicolumn{2}{l|}{$\begin{array}{l}\text { Norway } \\
\text { (other crab) }\end{array}$} & \multicolumn{2}{l|}{$\begin{array}{l}\text { China } \\
\text { (other crab) }\end{array}$} \\
\cline { 2 - 8 } & tons & USD per kg & tons & $\begin{array}{l}\text { USD per } \\
\text { kg }\end{array}$ & tons & $\begin{array}{l}\text { USD } \\
\text { per kg }\end{array}$ \\
\hline Total & 4814 & 27.94 & 681 & 37.44 & 3601 & 3.10 \\
\hline May & 269 & 50.75 & 35 & 38.33 & 466 & 2.89 \\
\hline June & 223 & 34.78 & 29 & 41.05 & 54 & 2.87 \\
\hline July & 95 & 25.01 & 167 & 43.01 & 0,2 & 3.00 \\
\hline August & 154 & 30.47 & 304 & 42.56 & 0 & - \\
\hline September & 642 & 26.31 & 38 & 40.70 & 20 & 3.70 \\
\hline October & 746 & 25.20 & 12 & 33.00 & 193 & 4.28 \\
\hline Total & 3490 & 32.96 & 783 & 41.26 & 2375 & 2.99 \\
\hline
\end{tabular}

Market experts note that the price situation favored the growth of Russian supplies, since the price level was even more beneficial from the point of view of Russian producers than in 2018, when at the end of the year prices increased by an average of $7 \%$ and reached more than USD 18.50 per $\mathrm{kg}$ (CIF). According to the results of the first ten months of this year, prices have already reached more than USD 20.00 per $\mathrm{kg}$ and increased by almost $13 \%$ compared to the previous year's results. However, in October they returned to less than USD 20.00 per $\mathrm{kg}$, but even declining by $13.5 \%$ compared to September and dropping below USD 18.70 per $\mathrm{kg}$, the average import price of Russian products turned out to be $10 \%$ higher than the average price of the previous year, so the price situation in 2019 was going favorably for Russian producers by early November [6-10].

In the aggregate, the increase in supply volumes and the price level rise basically ensured that the total value of imports by early November reached the level of USD 130.0 million. This is 30\% more than the value of imports in January-October 2018 and approximately $1.5 \%$ more than the annual value of Russian shipments for the entire previous year, which, in turn, was at least $45 \%$ more than in 2017. It means that the demand from the South Korean market does provide Russian producers and exporters of live snow crab with comfortable environment for sustainable operation.

Thus, the analysis of world prices for the products of the fishing industry showed a certain trend that can persist in the long term, but it is necessary to take into account the probability of risk events occurrence in the process of pricing policy assessment and establishment.

\section{Conclusions}

The trends identified in the course of the analysis make it possible to consider certain relationships with regard to the pricing policy, and on the basis of these conclusions and causality it is possible to point out the main directions of pricing policy development.

The main directions of improvement of pricing for agricultural products include the following:

- application of holistic approach for determination of prices at all stages of the production process;

- development of free pricing for agricultural products with government intervention only in case of threats to food security;

- limited level of prices for the products of monopolies;

- market protection with constant correspondence of domestic and world prices. 
In the process of implementation of these directions of pricing policy improvement for the products of agricultural sector it is necessary to solve the following tasks:

- to establish the unified methodological framework for pricing of agricultural products;

- to ensure the priority of the agro-industrial complex development;

- to guarantee the equivalence of exchange between the agro-industrial complex and other sectors of the national economy [11-15].

\section{References}

1. N. Reshetnikova, M. Magomedov, Smart Innovation, Systems and Technologies, 138, 399-408 (2020)

2. L. Medvedeva, IOP Conference Series: Earth and Environmental Science, 548(2), 1-5 (2020)

3. T. Marwa, A. Bashir, M. Azwardi, H. Thamrin, International Journal of Economics and Business Administration, 5(2), 69-82 (2017)

4. Z. Gornostaeva, Y. Sorokina, Lecture Notes in Networks and Systems, 73, 177-184 (2020)

5. V. Joao, Science of The Total Environment, 68820, 346-360 (2019)

6. M. Kabanenko, L. Dubrova, N. Andreeva, L. Orekhova, E. Ivanova, E3S Web of Conferences, 175, 06005 (2020)

7. V. Mazur, K.Barmuta, S. Demin, E. Tikhomirov, M. Bykovskiy, International Journal of Economics and Financial, 6(1S), 270-274 (2016)

8. Z. Gornostaeva, Lecture Notes in Networks and Systems, (73), 287-295 (2020)

9. V. Borisova, E. Panfilova, P. Zhukov, S. Matulis, V. Matveev, V. Teymurova, International Journal of Management and Business Research, 9 (1), 158-169 (2019)

10. Z. Gornostaeva, I. Kushnaryova, E. Alekhina, Advances in Intelligent Systems and Computing, 726, 207-216 (2019)

11. Z. Gornostaeva, N. Lazareva, M. Bugaeva, O. Gribova, N. Zibrova, International Journal for Quality Research, 13(2), 301-314 (2019)

12. I. Terenina, D. Kostoglodov, L. Kiyanova, O. Usatkina, International Journal of Economics and Business Administration, 7, 325-338 (2019)

13. O. Godina, Y. Kosenkova, L. Maksimenko, Y. Mezentseva, T. Shcherbakova, Advances in Intelligent Systems and Computing, 726, 118-127 (2019)

14. K. Barmuta, O. Grishchenko, E3S Web of Conferences, 175, 08003 (2020)

15. A. Solonenko, L. Medvedeva, Y. Mostovaya, E3S Web of Conferences, 175, 1-8 (2020) 